\title{
THE ROLE OF MANAGEMENT IN PROMOTING A MOTIVATIONAL WORK SETTING FOR NURSES
}

\section{Prof. Karien Jooste}

Associate Professor, Department of Nursing Sciences, RAU

Corresponding author: kjo@edcur.rau.ac.za

\section{Mr Oscar Kilpert}

Chief Educational Supervisor, Bureau for University Education, UNISA

Key terms: Motivation; Incentives; Rewards; Acknowledgements of work performances

\section{ABSTRACT}

The use of motivation and reward strategies is necessary for empowerment of staff members in their work situation. For motivation to occur in a health service, strategies should focus on self-motivation, expansion and enrichment of tasks, acknowledgement of work performances of nurses, rewards for outstanding service and constructive feedback by managers to nurses.

A descriptive, explorative study was done to investigate the current motivational strategies used in health services management settings. A sample of 112 nurses completed a questionnaire that provided information relating to the employer/health service (organisational culture, personal values and expectations), the direct supervisor of a staff member (working relationships, interpersonal skills of the supervisor) and self-concept.

Important strategies that should be employed by managers in the establishment of a motivational environment for staff are integrated into a conceptual framework.

The framework lends itself for planning of future in-service training of nursing staff members. Special attention will be given to the following nursing management principles:

- $\quad$ Nurses have to play their own role in the attainment of their personal objectives.

- Open acknowledgement of work performances of nurses is a priority.

- $\quad$ Nurses require support and positive feedback that fosters a feeling of self worth.

- Job descriptions should not prevent staff from moving beyond their core tasks.

- $\quad$ Change is needed in creating a new organisational climate that favours remuneration.

Based on the findings of this research study, the researcher sets out to illuminate the aspects fundamentally involved in maintenance of a motivational working climate for nursing staff members.

\section{ABSTRAK}

Die gebruik van motiverings- en beloningstrategieë vir die bemagtiging van personeellede in hulle werksituasie is nodig. Vir motivering, om in 'n gesondheidsdiens plaas te vind, behoort strategieë op selfmotivering, uitbreiding en verryking van take, erkenning van werkverrigting van verpleegkundiges, belonings vir uitstaande dienslewering en konstruktiewe terugvoer van bestuurders aan verpleegkundiges, te fokus.

'n Beskrywende, eksploratiewe studie is uitgevoer wat die huidige motiveringstrategieë wat in bestuursituasies in gesondheidsdienste gebruik word, ondersoek. 'n Steekproef van 112 verpleegkundiges het ' $n$ vraelys voltooi wat inligting aangaande die werknemer/gesondheidsdiens (organisatoriese kultuur, persoonlike waardes en verwagtinge), die direkte toesighouer van 'n personeellid (werksverhoudinge, interpersoonlike vaardighede) en selfkonsep voorsien het.

Belangrike strategieë wat deur bestuurders gebruik behoort te word in die vestiging van 'n gemotiveerde klimaat vir personeel, word in 'n konseptuele raamwerk vasgelê.

Hierdie raamwerk leen homself tot toekomstige beplanning van indiensopleiding vir verpleegpersoneel. Spesiale aandag sal aan die volgende bestuursbeginsels geskenk word: 
- Verpleegkundiges is self betrokke by die bereiking van hulle persoonlike doelwitte.

- $\quad$ Openlike erkenning van werkprestasies van verpleegkundiges is 'n prioriteit.

- Verpleegkundiges vereis ondersteuning en positiewe terugvoer wat' $n$ gevoel van selfwaarde bevorder.

- Werkbeskrywings behoort personeel nie te verhoed om buite hul kerntake te beweeg nie.

- Verandering is nodig in die skep van 'n nuwe organisatoriese omgewing wat beloning voorstaan.

Gebaseer op die bevindinge van hierdie navorsingstudie, poog die navorser om aspekte wat fundamenteel in die behoud van 'n motiverende werksklimaat vir verpleegpersoneellede is, uit te lig.

\section{BACKGROUND AND RATIONALE}

It is claimed that the word "motivation" is amongst the six most used words in company documents. Just because it is used, does not mean to say that it is understood or effectively implemented in an institution (Denny, 1994:7). In 1999 the following research priorities for the new millennium was identified by the Research Committee of the Democratic Nursing Organisation of South Africa (1999) following input from various sources:

- promotion of teamwork for effective human resources in health

- transformational management

- motivation in learning.

These research priorities relate to the importance of the role of the health services manager in motivation of health care employees.

Motivation is a key ingredient in achieving an effective and successful body of staff members in any health organisation. However, the current situation in health services indicates concerns in which nurses could experience a lack of motivation in their work environment. Klann (1992:20) points out that a tendency in the last twenty years is the decreasing of authority and autonomy of nurses in health services. The latter does not contribute to a motivated workforce. The restructuring of the economy and transformation in some countries, directly challenge the manager's task in motivating employees by increasing the sense of job insecurity and eroding the concept of company/institutional loyalty (Gee \& Burke, 2001:131).

Cooper (1999:569) is of the opinion that work is increasingly changing into a short-term contract culture, with long hours, intrinsic job insecurity and declining sense of loyalty by employees to their employer. The impact on the employee's health, the family and the health sector as the "bottom line" is great. A time for reflection is needed in the way we manage people's careers and futures.

Motivated nurses are needed to actively participate in organisational activities to ensure quality nursing care, cost effective service rendering, high morale and work productivity.

To motivate others is one of the most important tasks of management. Those who have the greater responsibility of managing or leading others should know what is necessary to help people achieve their own aspirations or how they can be motivated towards a common goal (Denny, 1994:9). It comprises the ability to communicate, to set an example, to challenge, to encourage, to obtain feedback, to involve, to delegate, to develop and train, to inform, to brief and to provide a just reward (Denny, 1994:7).

Motivation is also generally defined as "the arousal, direction, and persistence of behaviour" (Daft \& Lloyd, 2000:300). Studies on motivation thus concern what prompts people to initiate action, what influences their choice of action, and why they persist in doing it over time. This study was aimed at identifying important motivational needs of higher and lower levels of nurses/ managers that should be addressed in the future health services management situation.

If an organisation does not possess the ability to motivate its employees, the knowledge within the organisation is not practically used to a maximum. Therefore, it should become the aim of every successful organisation to find the factors that enable it to motivate its employees to continuous growth and learning and to take advantage of this knowledge to ensure its living (Osteraker, 1999:73).

It was not known how nurses in the Gauteng Province of South Africa viewed their motivational needs in the working situation. On the one hand, nurses need 
continuous motivation in their work situation to experience job satisfaction. On the other hand nurses have different motivational needs in their working environment

\section{PROBLEM STATEMENT}

The overall research question could thus be stated as follows:

What are the most important motivational needs of nurses in their work environment and how should they be addressed?

\section{PURPOSE AND OBJECTIVES}

The main purpose/aim of this research study was to help nurse leaders to understand what the most important motivational needs of nurses are, and what actions should be taken to motivate nurses effectively in their working environment. This primary aim was achieved through the following objective/question:

What role does the employer/health service play in the motivation of nurses?

\section{ASSUMPTIONS}

For this study the following assumptions were made:

- a person can motivate himselt/herself

- the concept motivation is presumed in different forms by different persons and in different contexts.

\section{LITERATURE STUDY}

The findings of various research studies outline important motivational variables in the work situation of health care professionals:

- Applebaum and Kamal (2000:733) indicates the affect of job enrichment, employee recognition, pay equity and managerial skill on the job satisfaction and motivation of employees.

- A recent factor analysis identified a group of factors including recognition and appreciation, salary and remuneration, promotional status and job satisfaction (Analoui, 2000:324).

A survey on motivating staff, conducted in Nigeria reveals that a general dissatisfaction regarding training opportunities, sabbatical leave, communication and management style, work environment and promotion prospects exists (Abifarin, 1997:124).

Another study outlines the environmental factors that impact on motivation of staff as approaches to financial rewards, the culture of staff development, the diversity of staff experience and roles, personal autonomy and organisational structure (Rowley, 1996:11).

A research study explored what motivated employees according to over 40 years of motivational surveys (Wiley, $1997: 263)$. The comparisons revealed that employees' motivational preferences vary over time. The results of the latter study indicated that the factors that motivate today's workers are more extrinsic than they used to be. Employees in the mentioned study overwhelmingly selected "good wages" as the top motivator. A good wage is an extrinsic reward with intrinsic potency. On the surface "good wages" seem to be purely extrinsic. Yet, at a deeper level, monetary rewards communicate what the institutional values are and affect employees' emotional and familial well-being. A South African television program called "Special Assignment" in April 2001 highlighted the need for better salaries for nurses and professional health care workers in health services in South Africa. Poor working conditions and salaries were the main reasons mentioned for health professionals leaving the country. On the other hand an empirical study done in the UK in 1999 found no association between financial incentives and job satisfaction or staff motivation (Smith, 1999:264). This indicates that the value of the pound plays a role in motivating staff members!

Scarcities of qualified personnel could be a substantial problem in securing an adequate workforce. At the same time, increasing wages to secure an adequate workforce is not always possible or sufficiently effective, and other ways of retaining and recruiting personnel have to be found. The importance of various job characteristics for retaining and recruiting employees should be investigated in South Africa. Job characteristics other than wages, such as labour relations and work content, were found to play a major role in individuals' choices to resign or stay in the job (Van de Looij \& Benders, 1995:27-33).

In the discussion that follows most of the above 
mentioned motivational concepts are addressed.

\section{CONCEPTUAL FRAMEWORK}

Figure 1 illustrates the conceptual framework of the motivational process that directed the research (Jooste, 1997). The three key components of the framework are the employer (work environment), the direct supervisor/ manager and the self concept of the nurse that contributed to self motivation, expansion and enrichment of tasks, acknowledgement of work performances of nurses, rewards for outstanding service and constructive feedback. This article focuses on the role of the employer in motivating nurses in their work situation.

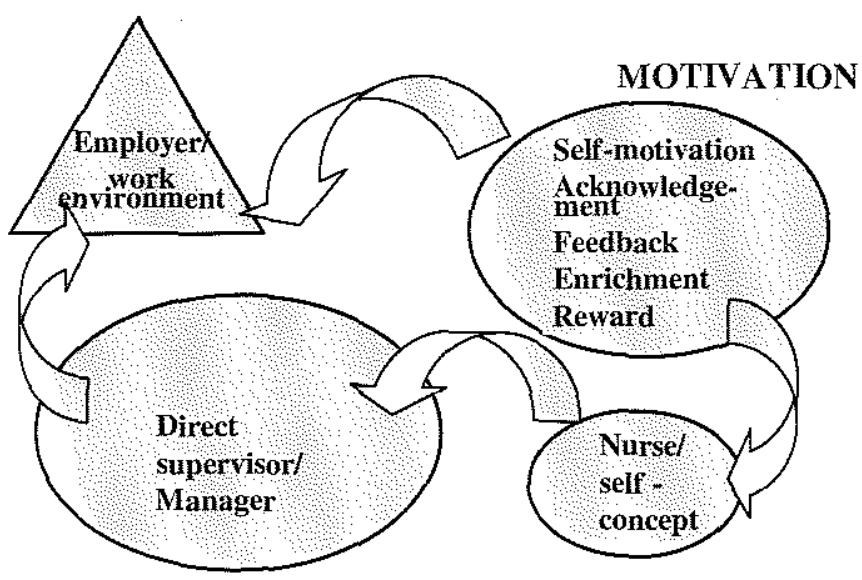

Figure 1: Conceptual framework

\section{METHODOLOGY}

To find (an) answer(s) to the overall research question, it was decided that a quantitative, descriptive, explorative study was the most appropriate method. The purpose of exploratory research is to gain insight into a situation, phenomenon, community or person (Bless \& HigsonSmith, 1995:42-44). A research instrument in the form of a Likert-type questionnaire was developed.

Ten expert nurse managers as well as a statistician critically evaluated the instrument in a pre-test. These nurse managers did not participate in the main study. Face and content validity were ascertained through experts in the field of Health Services Management who critically reviewed the questionnaire and suggested a few improvements thereof.

The final draft of the questionnaire was administered to all 112 second year students who were attending the laboratory workshops on Health Services Management II of the University of South Africa (Unisa) in the Gauteng Province. The total population was represented by 448 second year students registered for the second year practical course in Health Services Management. Convenience sampling was used and 112 second year students participated in the research study. In this sampling the researcher selected those respondents who were "close at hand" during the workshops and time and effort were saved. "What was lost in accuracy was gained in efficiency" (Guy, Edgly, Arafat \& Allen, 1987:189). Conclusions were drawn from the available responses that could influence the generalisability of the findings of the study to a broader population of health services managers in the Gauteng Province.

The 120 items in the questionnaire were based on the three components of the conceptual framework, namely the employer (working environment), the direct supervisor/manager and the self concept of the nurse in establishing an effective motivational environment for nurses. Content validity was tested by the fact that the items represented the conceptual framework of the study.

From an item analysis on the research data, a Cronbach alpha (a) of 0,839 was obtained, indicating a reasonably reliable instrument (Guy, et al. 1987:171).

\section{LIMITATIONS AND ETHICAL CONSIDERATIONS}

The following limitations were identified in this study:

- The choice of the Gauteng Province under study was based on non-probability sampling, which limits the generalisation of the findings.

- The findings relate to a small size of only 112 health services management students that may not be representative of the entire population of students registered for the practical course in Health Services Management II.

Ethical issues were taken into consideration. Participants were ensured of anonymity. Informed consent was obtained before the questionnaires were completed. All participation was voluntary.

FINDINGS, CONCLUSIONS AND 


\section{RECOMMENDATIONS}

\section{General background of the respondents}

The research group (figure 2) consisted of 112 nurses who were placed on different levels in the hierarchy of public and private health services. Higher level nurses were represented by nursing service managers (10 percent) and chief professionals nurses (20 percent). Lower level nurses were represented by senior professionals nurses (38 percent) and professional nurses (32 percent).
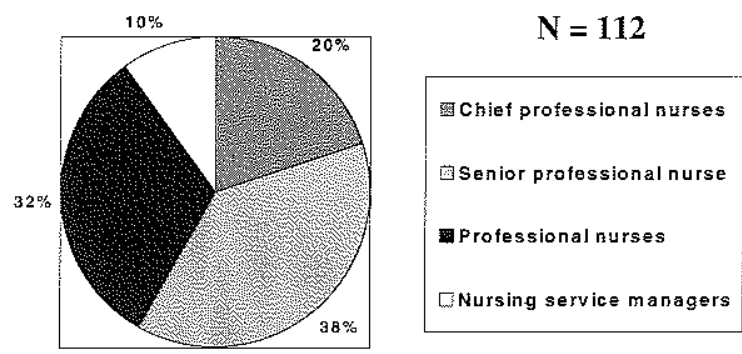

Figure 2: Position within the service

A number of 68 percent respondents $(n=74)$ were working five years and less in their current positions (table 1). It was assumed that they still had their nursing career ahead of them.

Table 1: Years in current position

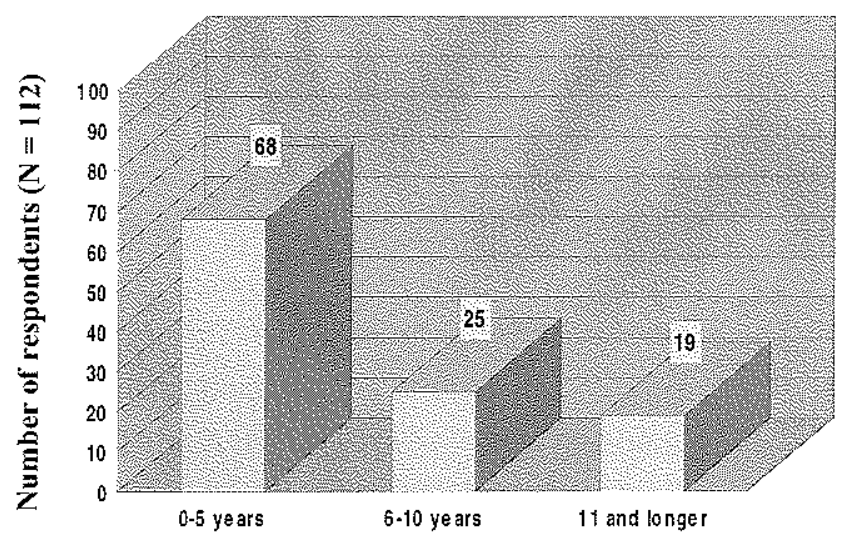

Sixty six percent of the respondents worked in the public sector (table 2). It is well known that the private sector is more focussed on participative management and motivation than the public sector.

The respondents were well represented in all spheres of the nursing service namely teaching, hospital wards,
Table 2: Type of service

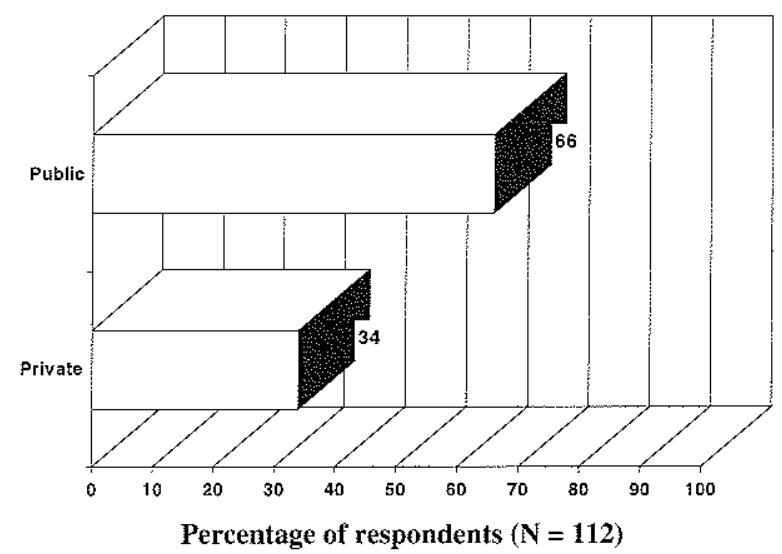

clinics, hospital administration, rural clinics, casualty services, poli clinic, intensive/high care, and theatre (figure 3).

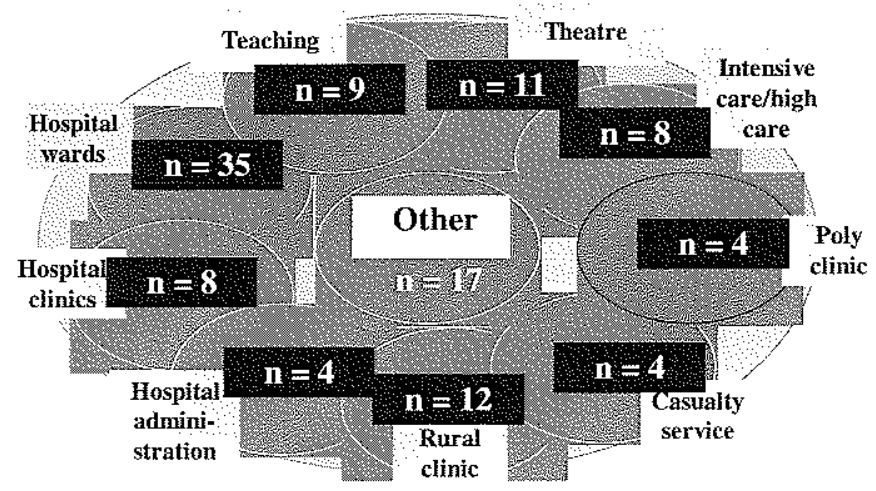

Figure 3: Disciplines/working situation $(\mathrm{N}=112)$

\section{Job satisfaction/dissatisfaction and the Hertzberg's Two-factor theory}

In this study the concept job satisfaction was viewed as an indicator of work motivation.

A principal component factor analysis with a Varimax rotation on the 60 items of section $B$ of the questionnaire regarding the employer, lead to interesting findings. Seven key factors were identified as areas of satisfaction or dissatisfaction in the health service (table 3 ).

\section{Job dissatisfaction in health services}

Areas of dissatisfaction (table 3) were identified as: strategic planning (Factor 1), autocratic management/ rules (Factor 2), financial management (Factor 3 ) and strict discipline (Factor 4). According to Hertzberg's TwoFactor Theory, areas of dissatisfaction are called Hygiene factors (Dienemann, 1998:361-362). 
Table 3: Factor analysis - The emloyer/health service Areas of dissatisfaction and satisfaction

\begin{tabular}{|c|l|l|l|}
\hline Factor 1 & Strategic planning & Factor 5 & Responsibilities \\
\hline Factor 2 & $\begin{array}{l}\text { Autocratic management/ } \\
\text { rules }\end{array}$ & Factor 6 & Work itself \\
\hline Factor 3 & Financial management & Factor 7 & Personal growth \\
\hline Factor 4 & Strict discipline & & \\
\hline
\end{tabular}

When these hygiene factors are poor, work is dissatisfying. Good strategic planning, rules and effective financial management will therefore remove the dissatisfaction among nurses, but they do not in themselves cause nurses to become highly satisfied and motivated in their work.

Respondents were of the opinion that dissatisfaction among nurses in the health service was due to the following reasons:

- the service has lots of people in motion but not much is getting done (factor 1);

- management believe that the way the organisation has always done a job is the only way to do it (factor 2);

- the service has trouble with political games and backstabbing when it comes to salary raises, promotions and perks (factor 2);

- $\quad$ nurse managers find it nearly impossible to make rapid changes or decisions because of a morass of policies, forms, procedures and committees (factor 2);

- management ought to be more approachable at all times (factor 2);

- the service pays some of the highest salaries at a given level to the recently hired (factor 3 ); and - $\quad$ the service awards the largest budget increases and new staff positions to those who spend the most (factor 3).

The above mentioned factors are important because they reduce job dissatisfaction, but they will not result in an increase in satisfaction/motivation (Dienemann, 1998:361).

Some research studies indicate that income/money/pay is a moderating factor with regard to the success of nonmonetary incentives. Findings indicate that recognition, job enrichment and job satisfaction are most effective when supplemented with an income that allows employees to meet physiological and security needs for themselves and their families. By doing so productivity of existing and potential employees is increased (Applebaum \& Kamal, 2000:733).

\section{Job satisfaction in health services}

Culture is the set of key values, beliefs and understanding shared by members of the organisation (Daft \& Lloyd, 2000:44). Each organisation requires a culture that supports the mission and objectives of the organisation. In a recent study of Minnaar (2001:205) only $46 \%$ of respondents indicated that the culture in their hospitals was one of caring in which people were inspired to work. As human beings we all long for an experience at work that we can feel that "wow" experience that inspire humans. Hospitals and health care settings should provide environments for health professionals and workers to be inspired towards growth, development and motivation in their professions. The key success factors basic to the successful growth and survival of the institution were identified in factors 5, 6 and 7 - the motivators.

The three main areas of satisfaction in the health service were identified as motivational factors namely: responsibilities (Factor 5), the work itself (Factor 6 ) and personal growth and belonging (Factor 7 ).

It is the motivators (e.g. the job challenges, autonomy, responsibility) that are the basis for the feelings of job satisfaction (Dienemann, 1998:361). Respondents were of the opinion that job satisfaction in the work place is promoted by the following:

- Responsibilities (table 4): clear job responsibilities and goals that have been set with the supervisor to reach them, communication channels in the organisation that are known to employees, and open and good relationships between different departments in the organisation (Factor 5).

- Work itself (table 5): delegating responsibility with accountability, listening to and considering the initiatives and ideas of employees, placing more focus on how to correct things, rather than blaming each other, and the right to disagree with staff members without fearing reprimand 
(Factor 6). According to research conducted by Groot and Van den Brink (1999:343) in the Netherlands, satisfaction with the job content is the main factor explaining overall job satisfaction. This research also indicates that skill mismatches do not seem to affect job satisfaction and that the effects of individual and job characteristics on job satisfaction differ by the aspect of the job considered.

- $\quad$ Personal growth and belonging (table 6): a feeling of belonging in the organisation and when there are few rumours in the organisation (Factor 7).

Table 4: Items with significant values regarding organisational culture (factor 5 )

\begin{tabular}{|c|c|c|c|}
\hline Factor 5 & Item & Value & Theme \\
\hline \multirow[t]{3}{*}{ sponsibilities } & 11 & 0,63 & $\begin{array}{l}\text { Responsibilities } \\
\text { clear and goals se }\end{array}$ \\
\hline & 12 & 0,60 & $\begin{array}{l}\text { Communication } \\
\text { channels }\end{array}$ \\
\hline & 13 & 0,67 & $\begin{array}{l}\text { Open working } \\
\text { relationships }\end{array}$ \\
\hline
\end{tabular}

Table 5: Items with significant values regarding organisational culture (factor 6 )

\begin{tabular}{|c|c|c|c|}
\hline Factor 6 & Item & Value & Theme \\
\hline \multirow[t]{4}{*}{ Work itself } & 16 & 0,64 & $\begin{array}{l}\text { Duties delegated with } \\
\text { accountability }\end{array}$ \\
\hline & 17 & 0,40 & Utter ideas \\
\hline & 20 & 0,54 & Positive focus \\
\hline & 21 & 0,81 & Open discussions \\
\hline
\end{tabular}

Table 6: Items with significant values regarding organisational culture

\begin{tabular}{|c|c|c|c|}
\hline Factor 7 & Item & Value & Theme \\
\hline $\begin{array}{l}\text { Personal } \\
\text { growth }\end{array}$ & 22 & 0,81 & $\begin{array}{l}\text { Positive working } \\
\text { climate }\end{array}$ \\
\hline
\end{tabular}

Satisfaction creates confidence, loyalty and ultimately, improved quality in the output of the employed (Tietjien \& Myers, 1998:226).

\section{Needs Theory}

Human needs act as motivators (Dienemann, 1998:462). Maslow's hierarchy of needs is well known to health care practitioners. It was recognised that human beings have intrinsic needs that influence their work behaviour. Maslow's contention is that once lower-level physiological and security needs are met, workers are motivated by the higher order needs.

Responses indicated that in the lower level of the Needs Theory the safety and good working conditions were still valued as highly needed by nurses (table 7). Significant differences in opinions were identified in the higher level of esteem, where it was clear that respondents were motivated by the need for recognition, high status, does preferred work/take decisions, and self respect.

Table 7: Motivational concepts in the working environment

Hierarchy of

Needs Theory

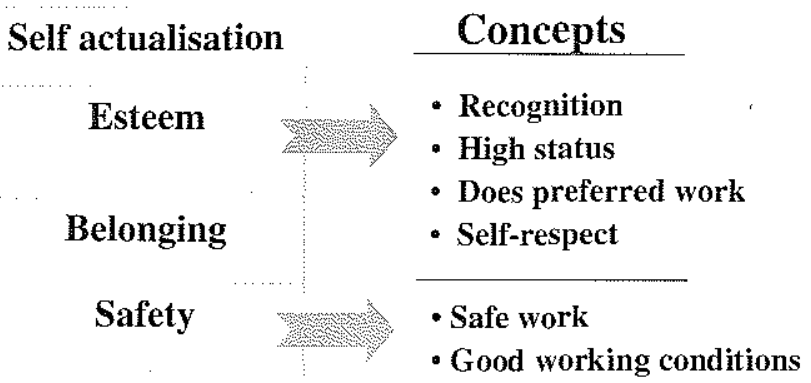

Physiological

Significant differences between the expectations of nurses on the higher and lower levels in the hierarchy were found to exist in health services with regard to motivational and reward concepts in the working environment (table 8). Respondents were asked how much they would care if certain motivational concepts in their working environment were greatly reduced:

- It seemed that the higher the position of a nurse in the organisational structure $\$ 61 \%$ top level managers), the more self respect as a higher order motivational need was perceived as 
important $\left(X^{2}=8,02, p<0,05\right)$.

- The same tendency was found in the item regarding recognition. More higher level nurses $(61 \%)$ than lower level nurses $(38 \%)$ were of the opinion that recognition was an important higher order motivational influence in the working environment $\left(\mathrm{X}^{2}=7,04, p<0,05\right)$.

- Only a small number of lower level nurses versus approximately half $(42 \%)$ of the higher level nurses were of the opinion that high status is important as a motivational concept in the working environment $\left(X^{2}=13,33, p<0,01\right)$.

- A vast majority of approximately 91 percent top level nurses valued the participation in decisions as very useful versus only 30 percent of the lower level nurses. It seems that the higher level nurses have more opportunities to concentrate on tasks they preferred doing $\left(X^{2}=12,66, p<\right.$ $0,01)$.

Table 8: Significant differences in opinion between nurses/managers regarding motivational concepts in the working environment $(\mathrm{N}=112)$

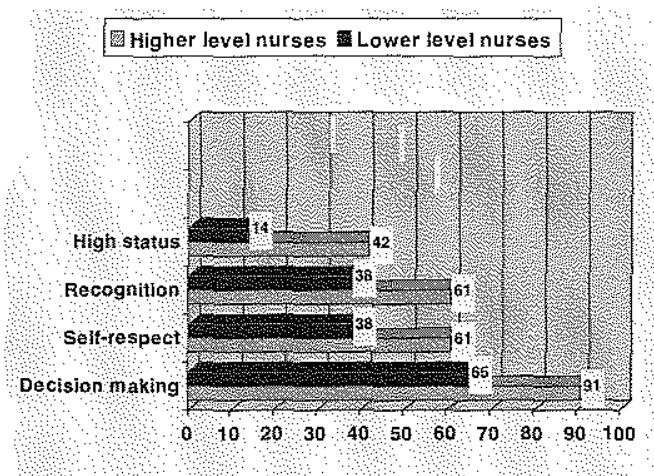

Percentage of nurses/managers $(N=112)$

It is interesting to note that the higher the level of the nurse in the hierarchy of the service the more important they acknowledged higher order motivational needs such as recognition, self respect, participation in decisionmaking and high status in their working environment. This could be due to fulfilment of their basic motivational needs on the lower levels of Need theory. It thus seems that the lower the position of a nurse in the hierarchy the more lower order motivation and incentive needs are viewed as important. In a research study done in 1999 it was found that most senior professionals had unfilled needs only at higher levels of the needs hierarchy. It was also pointed out that an individual's exact level on the needs hierarchy will vary from person to person with differences between supervisors and their staff. A number of research findings have suggested that managers are, in general, more satisfied with and motivated in their jobs than are workers/subordinates (Oshagbemi, 1999:108).

\section{The general working situation}

In more significant differences between the opinions of respondents working in the public and private health sectors, on the motivational concepts in their working environment, the following were identified:

- The respondents working in private health institutions $(51 \%)$ were much more positive towards the motivational concept of doing preferred work than their counterparts (27\%) working in the public sector $\left(\mathrm{X}^{2}=7,36, p<0,05\right)$.

- Only sixteen percent of the respondents working in the public sector versus 33 percent of their colleagues in the private sector acknowledged the fact that nurses have a need for safety in their current working situation $\left(\mathrm{X}^{2}=6,52, p<\right.$ $0,05)$.

- The majority of private employees (63\%) versus the minority of public employees $(36 \%)$ viewed the motivational concept of recognition as important $\left(X^{2}=7,34, p<0,05\right)$.

- The same tendency was found in the item regarding good working conditions. Nearly two thirds $(66 \%)$ of respondents working in the private sector versus only 42 percent of respondents employed in public health services viewed good working conditions as an important motivator in their work situation $\left(X^{2}=6,68, p<\right.$ $0,05)$.

It seems that the respondents employed in the private sector attach more value to certain motivational concepts such as does preferred work, recognition, safety and good working conditions than their counterparts working in the public health institutions.

The above responses indicate that the majority of motivational needs of the respondents exist on the safety and esteem levels of Maslow's Theory. According to Du Rand and Vermaak (1995:29) individuals who experience inadequate recognition experience a lack of motivation. It was 
also suggested that attention should be given to the job satisfaction of nurses and the acceptance of nurses as unique human beings.

Respondents ( $n=112$ ) were also asked to identify the five most important motivational concepts needed in their work situation in sequence of importance (table 9). The results (frequencies) indicated

- responsibility as most important concept, then followed by

- self-respect

- interaction with others

- safety and

- $\quad$ good working conditions.

Table 9: The value of motivational concepts in the work environment - important concepts $(\mathrm{N}=112)$

\begin{tabular}{|l|c|c|}
\hline $\begin{array}{l}\text { Motivational concepts of } \\
\text { high value }\end{array}$ & \multicolumn{2}{|c|}{$\begin{array}{c}\text { Number of respondents that } \\
\text { allocated a value of } 7 \text { to the item } \\
(\text { n) }\end{array}$} \\
\hline Responsibility & 60 & 53,6 \\
\hline Self-respect & 55 & 49,1 \\
\hline Interaction with others & 47 & 42,0 \\
\hline Safety & 42 & 37,5 \\
\hline Good working conditions & 38 & 33,9 \\
\hline
\end{tabular}

The importance of responsibility is also pointed out in a very recent study on career motivation, where Leung and Clegg (2001:12-20) found that younger executives had higher levels of job motivation and were striving to attain additional responsibility and authority in work assignments. On the other hand senior executives were more concerned with holding on to their previous accomplishments and competence in their occupational role.

The concept of good working conditions, is closely linked with the importance of corporate wellness programmes. Organisations in Singapore and elsewhere have begun to successfully implement wellness programmes on an organisation-wide scale with emphasis on a healthy lifestyle and improved health of employees and the broader public. Findings from a research study undertaken in Singapore in 1997 indicate that employees in organisations with wellness programmes generally have a more positive and motivated attitude towards their organisations and express higher job satisfaction (Ho, 1997:177). The point I would like to make is that management should not hesitate to adopt health promotion activities in the workplace.

In this study, the 112 respondents identified the least important motivational concepts in the working environment as self-guidance, food and clothes, and high status (table 10).

Table 10: The value of motivational concepts in the work environment - least important aspects $(N=112)$

\begin{tabular}{|l|c|c|}
\hline $\begin{array}{l}\text { Motivational concepts of } \\
\text { lower value }\end{array}$ & \multicolumn{2}{|c|}{$\begin{array}{c}\text { Number of respondents that } \\
\text { allocated a value of 7 to the item } \\
(\%)\end{array}$} \\
\hline Self-guidance & 27 & 24,1 \\
\hline Food and clothes & 19 & 17,0 \\
\hline High status & 14 & 12,5 \\
\hline
\end{tabular}

It was interesting to note that in the findings from a study undertaken in Russia and Poland the two most important motivators to employees were pay and friendliness of co-workers. In most cases, managers' perceptions of job motivators were similar to their employees (Huddleston \& Good, 1999:383). These motivators are focussed on the lower levels of the needs theory.

\section{Rewards and the job}

Respondents were asked to indicate the important personal values and expectations of their job. Responses on the personal values and expectations of the job were analysed according to extrinsic and intrinsic rewards (table 11).

Table 11 indicates the number of respondents who allocated the highest value of seven (7) to the most important values and expectations of their daily job. An intrinsic reward is the internal satisfaction a person receives in the process of performing a particular action (Daft 1999:239). Individual rewards were identified as

- health

- $\quad$ self respect and

- personal development.

Individual rewards may differ among nurses within the same organisation. An extrinsic, individual reward should be seen as a bonus, where an intrinsic, individual reward would be a sense of self-fulfilment that a nurse derives 
from her/his own work.

Extrinsic rewards are given by another person/supervisor and include promotions and pay increases (Daft, 1999:239). In this study the system wide rewards were identified as loyalty (as being part of a winning organisation) and economic security. System-wide rewards apply the same to all nurses within an organisation or department (Daft, 1999:239). Although this study did not focus on it, managers in different career stages could have distinct intrinsic and extrinsic reward preferences that may ultimately affect motivation and productivity. It is important to keep in mind that the perceived importance of various rewards for staff could be influenced by their career stage. This issue could be addressed in future research studies.

Table 11: The value of motivational concepts in the work environment - important concepts $(\mathrm{N}=112)$

\begin{tabular}{|l|l|l|}
\cline { 2 - 3 } Individual & Extrinsic & Intrinsic \\
\cline { 2 - 3 } & Personal & Health \\
& development & $(96,5 \%)$ \\
& $(95,6 \%)$ & Self-respect \\
& & $(95,6 \%)$ \\
\hline \multirow{5}{*}{ System wide } & Loyalty \\
\cline { 2 - 3 } & Economic & $(94,7 \%)$ \\
& security & \\
\hline
\end{tabular}

\section{RECOMMENDATIONS}

From the responses regarding the working environment and the management structure it is clear that specific motivational needs should be addressed by specific motivational systems. In future strategies for the motivation and empowerment of nurses, supervisors should focus on the following (figure 4):

- Promotion of self-motivation strategies and acknowledgement of work performances of nurses are essential to address the belonging and personal growth needs of nurses. Drew (1992:18) is also of the opinion that it is important to acknowledge the quality of nursing behaviours and quality performances. Corporate pep talks can be useful. The need for responsibilities, recognition and high status should be fulfilled.

- Expansion and enrichment of tasks, giving more new and creative responsibilities along with authority should be emphasised. Hereby nurses' needs regarding work itself, doing preferred work, good working conditions and safety are addressed.

- More attention should be paid to incentives and rewards for outstanding service. Expert individuals can receive an incentive by giving them the choice which project should be started next (Kanter, 1989:91). New incentive programmes can be introduced in health care settings that will lead to economic security, personal development, health, self-respect and loyalty of nurses.

- $\quad$ Constructive feedback by managers to nurses should be a priority. According to Kinlaw (1995:78) motivated individuals require more frequent feedback about their work performances. Managers should talk with staff members on a regular basis (interaction) and should be able to carry out on-the-spot assessments, listen to and praise staff as the case may be (Abifarin, 1997:124).

Figure 4: Future motivational strategies

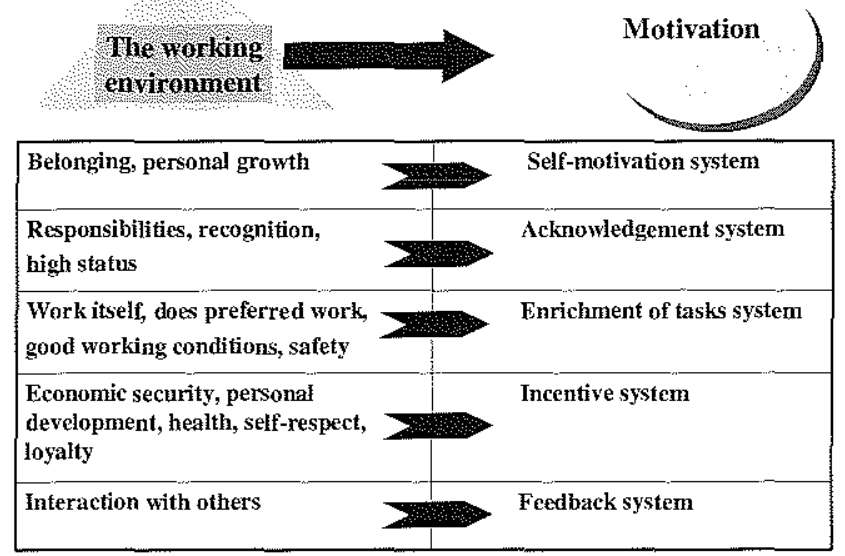

In future, training in motivational management is proposed, making managers more aware of how to fulfil the motivational needs of staff at several levels.

A study on managerial job satisfaction done in Hong Kong confirmed that the work environment, the job itself and rewards are critical factors in the motivation and job satisfaction of managers (Lam, Baum \& Pine, 2001:35).

\section{CONCLUSION}

Change is needed in creating a new organisational 
climate that favours motivation of employees. Job descriptions should not prevent staff from moving beyond their core tasks and open acknowledgement of work performances of nurses is a priority. Nurses require support and positive feedback that fosters a feeling of self worth.

\section{BIBLIOGRAPHY}

Abifarin, A 1997: Motivating staff in Nigerian university libraries. Library management, 18(3):124-128.

Analoui, F 2000: What motivates managers? Journal of Managerial Psychology, 15(4):324-340.

Applebaum, SH \& Kamal, R 2000: An analysis of the utilization and effectiveness of non-financial incentives in small business. The Journal of Management Development, 19(9):733-763.

Bless, C \& Higson-Smith, C 1995: Fundamentals of social research methods. An African perspective; 2nd edition. Juta: Cape Town.

Cooper, CL 1999: Can we live with the changing nature of work? Journal Of Managerial Psychology, 14(7):569-572.

Daft, RL 1999: Leadership. Theory and practice. London: Harcourt College.

Daft, RL \& Lloyd, TW 2000: Instructor's manual to accompany Management; 5th edition. Fort Worth: Harcourt College.

Democratic Nursing Organisation of South Africa 1999: Research priorities for the new millennium, Nursing Update, November.

Denny, R 1994: Motivate to win. Tested techniques for greater achievement. Kogan: London.

Dienemann, JA 1998: Nursing administration. Managing patient care; 2nd edition. Appleton \& Lange: London.

Drew, EH 1992: Winning with quality values, in the 75th Symposium Series - Leadership and empowerment for total quality, report number 992, pp. 17-18. New York: Conference Board.

Du Rand, PP \& Vermaak, MV 1995: Houding, kennis en geluk van verpleegpersoneel wat in tehuise van bejaardes werksaam is. Curationis, 18(1):26-33.

Gee, C \& Burke, ME 2001: Realising potential: the new motivation game. Management Decision, 39(2):131-137.

Groot, W \& Van den Brink, H 1999; Job satisfaction of older workers. International Journal of Manpower, 20(6):343-360.

Guy, RF; Edgly, CE; Arafat, I \& Allen, DE 1987: Social research methods: puzzles and solutions. Boston: Allyn and Bacon.

Ho, JTS 1997: Corporate wellness programmes in Singapore: effect on stress, satisfaction and absenteeism. Journal Of Managerial Psychology, 12(3):177-189.

Huddleston, P \& Good, LK 1999: Job motivators in Russian and Polish retail firms. International Journal Of Retail \& Distribution Management, 27(9):383-393.
Jooste, $\mathrm{K}$ 1997: ' $\mathrm{n}$ Model vir die bemagtiging van verpleegkundiges. 'n Bestuursperspektief. Pretoria: Unisa. (D. Litt et Phil.) Kanter, RM 1989: The new managerial work. Harvard Business Review, November/December: 85-92.

Kinlaw, DC 1995: The practice of empowerment. Making the most of human competence. England: Gower.

Klann, S 1992: Empowered teams build participative systems. ORManager, 8(2):20-21.

Lam, T; Baum, T\& Pine, R 2001: Study of managerial job satisfaction in Hong Kong's Chinese restaurants. International Journal of Contemporary Hospitality Management, 13(1):35-42.

Leung, ASM \& Clegg, SR 2001: The career motivation of female executives in the Hong Kong public sector. Women in Management Review, 16(1):12-20.

Minnaar, A 2001: An exploration of the presence and enactment of caring in the human resource management of nurses in KwazuluNatal Hospitals. University of Natal. (D. Litt. et Phil.)

Osteraker, M 1999: Measuring motivation in a learning organisation. The Journal of Workplace Learning, 11(2):73-77.

Oshagbemi, T 1999: Academics and their managers: a comparative study in job satisfaction. Personnel Review, 28(1):108-123.

Rowley, J 1996: Motivation and academic staff in higher education. Quality Assurance In Education, 4(3):11-16.

Smith, L 1999: An evaluation of programmes for staff motivation in NHS and hotel ancillary staff. Facilities, 17(7):264-271.

Tietjen, MA \& Myers, RM 1998: Motivation and job satisfaction. Management Decision, 36(4):226-231.

Van de Looij, F \& Benders, J 1995: Not just money: Quality of working life as employment strategy. Health Manpower Management, 21(3):27-33.

Wiley, C 1997: What motivates employees according to over 40 years of motivation surveys. International Journal Of Manpower, 18(3):263-289. 